\title{
Single mitochondrial gene barcodes reliably identify sister-species in diverse clades of birds
}

\author{
Erika S Tavares* ${ }^{* 1}$ and Allan J Baker ${ }^{\dagger 1,2}$
}

Address: ${ }^{1}$ Department of Natural History, Royal Ontario Museum, 100 Queen's Park, Toronto, Canada and ${ }^{2}$ Department of Ecology and Evolutionary Biology, University of Toronto, Toronto, Canada

Email: Erika S Tavares* - erika.tavares@utoronto.ca; Allan J Baker - allanb@rom.on.ca

* Corresponding author †Equal contributors

Published: 9 March 2008

BMC Evolutionary Biology 2008, 8:8| doi:|0.|| 86/|47|-2|48-8-8|

This article is available from: http://www.biomedcentral.com/I47I-2/48/8/8I

(c) 2008 Tavares and Baker; licensee BioMed Central Ltd.

This is an Open Access article distributed under the terms of the Creative Commons Attribution License (http://creativecommons.org/licenses/by/2.0), which permits unrestricted use, distribution, and reproduction in any medium, provided the original work is properly cited.
Accepted: 9 March 2008
Received: 29 December 2007

\begin{abstract}
Background: DNA barcoding of life using a standardized $\mathrm{COI}$ sequence was proposed as a species identification system, and as a method for detecting putative new species. Previous tests in birds showed that individuals can be correctly assigned to species in $\sim 94 \%$ of the cases and suggested a threshold of $10 \times$ mean intraspecific difference to detect potential new species. However, these tests were criticized because they were based on a single maternally inherited gene rather than multiple nuclear genes, did not compare phylogenetically identified sister species, and thus likely overestimated the efficacy of DNA barcodes in identifying species.

Results: To test the efficacy of DNA barcodes we compared $\sim 650$ bp of $\mathrm{COI}$ in 60 sister-species pairs identified in multigene phylogenies from 10 orders of birds. In all pairs, individuals of each species were monophyletic in a neighbor-joining $(\mathrm{NJ})$ tree, and each species possessed fixed mutational differences distinguishing them from their sister species. Consequently, individuals were correctly assigned to species using a statistical coalescent framework. A coalescent test of taxonomic distinctiveness based on chance occurrence of reciprocal monophyly in two lineages was verified in known sister species, and used to identify recently separated lineages that represent putative species. This approach avoids the use of a universal distance cutoff which is invalidated by variation in times to common ancestry of sister species and in rates of evolution.

Conclusion: Closely related sister species of birds can be identified reliably by barcodes of fixed diagnostic substitutions in $\mathrm{COI}$ sequences, verifying coalescent-based statistical tests of reciprocal monophyly for taxonomic distinctiveness. Contrary to recent criticisms, a single DNA barcode is a rapid way to discover monophyletic lineages within a metapopulation that might represent undiscovered cryptic species, as envisaged in the unified species concept. This identifies a smaller set of lineages that can also be tested independently for species status with multiple nuclear gene approaches and other phenotypic characters.
\end{abstract}

\section{Background}

Large scale sequencing of a predefined region of approximately 650 (base pairs) bp of the mitochondrial gene COI, known as DNA barcoding, has two main goals: 1) to develop a species identification system that also allows unknown individuals to be assigned to species; 2 ) and to enhance the discovery of new species [1-3]. Although DNA barcoding has proved effective in achieving both 
goals in several large groups of animals [4-11], the efficacy of the tests have been questioned [12-16].

A major test performed on 643 previously recognized species of birds of North America demonstrated the effectiveness of DNA barcoding because $94 \%$ possessed unique monophyletic COI clusters $[10,11]$. The remaining $6 \%$ of the species did not have unique DNA barcodes, indicating that they either were (a) wrongly identified in the past as separate species, (b) closely related species that hybridize regularly, or (c) species losing identity by secondary contact [11]. These groups may be in the indeterminate zone between differentiated populations and distinct species $[10,11]$. Critics of DNA barcoding claim that in spite of the impressive number of bird species sampled [11], the precision of the method was compromised due to insufficient intraspecific sampling, and because comparisons among species were not exclusively from sister-species pairs $[12,15,17]$, where taxonomic uncertainty, interspecific hybridization, and incomplete lineage sorting could decrease the effectiveness of the test [12]. The suggested threshold of 10 times the mean intraspecific variation (10 $x$ rule) to screen for splits referred to as 'putative' species [11] has also been criticized. Moritz and Cicero [12] reported significantly lower average mitochondrial DNA distances between sister species of birds than levels reported in the barcoding tests of birds $[10,11]$, although the distances from these sister-species comparisons came from a variety of methods and genes [7]. Meyer and Paulay [13] tested different threshold methods in COI barcodes of cowries and found extensive overlap of overall intraspecific distances with interspecific distances, resulting in minimum error rates of $\sim 17 \%$ to screen for putative new species. Additionally, a simulation study using the neutral coalescent and the BatesonDobzhansky-Muller (BDM) model of speciation suggested that mtDNA barcodes will have error rates lower than $10 \%$ in assigning individuals to species only when populations have been isolated for more than 4 million generations [15]. A universal-distance cutoff is therefore not an objective criterion to delineate species limits [18].

Additionally, Hickerson et al. [15] argued that reciprocal monophyly of mtDNA sequences and the $10 \times$ threshold will likely underestimate species diversity [15]. Tree-based approaches with genetic distances that use reciprocal monophyly for species delimitation can be problematic because aggregations of haplotypes in phylogenetic trees, even when highly supported, do not necessarily imply that they belong to a distinctive taxonomic unit [19]. To address these issues, Rosenberg [19] proposed a statistical test to test if monophyletic groups in a phylogenetic tree are more likely to represent distinctive taxonomical entities, or are just random branches of lineages within a species. This approach also suggests minimal sample sizes required for inferences to be made about taxonomic distinctiveness from observations of monophyly [19].

Some of the advantages of using a single mtDNA barcode to identify species are that it has a higher rate of evolution (and thus more mutations), and because matrilineal lineages sort into reciprocally monophyletic clades much faster than nuclear genes [20]. This reduces the incidence of incompletely sorted lineages relative to that expected with nuclear genes. However, recent simulations with multiple nuclear genes indicate that very recently derived species can be identified well before the time to reciprocal monophyly [21]. Additionally, species were correctly delimited in $<50 \%$ of replicates simulating mtDNA sequences, suggesting that the single gene barcode approach was insufficient to delimit recently diverged species.

In response to the above criticisms we initiated a more comprehensive study of 60 sister-species pairs of birds defined rigorously with multigene phylogenies to determine whether mtDNA barcodes can reliably distinguish closely related sister species. Instead of the much criticized $10 \times$ rule, which may not apply in recently diverged sisterspecies pairs, we use coalescent-based statistical tests for species distinctiveness under reciprocal monophyly [19]. Additionally, we show that even recently diverged sisterspecies pairs have fixed nucleotide substitutions that serve as diagnostic mtDNA barcodes envisioned in the original analogy. Such diagnostic barcodes are useful not only in quickly identifying known species of birds but also in flagging other recently derived evolutionary lineages that could be analyzed with multilocus methods [21-23] to determine if they represent emergent species.

\section{Results}

\section{DNA barcodes distinguish sister-species of birds}

Monophyletic clusters of individuals corresponding to species were recovered in a Neighbor-joining (NJ) tree under the Kimura 2-parameter (K2P) model in all the sister-species pairs compared (Table 1, see Additional files 1 , 2). Multiple diagnostic characters in the branches of the trees leading to species clusters were detected in all the pairs (see Additional file 1, Figure 1). Bootstrap support at the nodes grouping individuals of the same species varied from 55 to $100 \%$, except for Eastern Meadowlark (Sturnella magna), with the majority of the values $(93.1 \%)$ above $85 \%$ (see Additional file 1). Species with clusters of individuals supported with bootstrap levels below 85\% were: Ruby-throated Hummingbird (Archilochus colubris), Black-chinned Hummingbird (Archilochus alexandri), Gunnison Sage-Grouse (Centrocercus minimus), Dusky Grouse (Dendragapus obscurus), Nuttall's Woodpecker (Picoides nuttallii), Jackass Penguin (Spheniscus demersus), and Magellanic Penguin (Spheniscus magellanicus). These 
Phalaropes (Phalaropus)

\begin{tabular}{|l|l} 
A & \\
& \\
& BROM133-06 Cambridge Bay, CA \\
KRBNA431-05 Alaska, USA \\
BROM134-06 Peru \\
KKBNA430-05 Alaska, USA \\
KKBNA429-05 Anadyr, Russia \\
KKBNA287-05 Lun skiy Zaliv, Russia \\
KKBNA281-05 Anadyr, Russia \\
KKBNA210-05 Point Defiance, USA \\
BOTW273-05 Point Defiance, USA \\
BROM137-06 Peru \\
BROM136-06 Peru \\
\hline B. lobatus \\
BROM129-06 Taymyr Pen, Russia \\
BROM131-06 Bay of God's Mercy, CA \\
BROM132-06 Bay of God's Mercy, CA \\
TZBNA125-03 Cornwallis Is, CA \\
TZBNA134-03 Baffin Is, CA
\end{tabular}

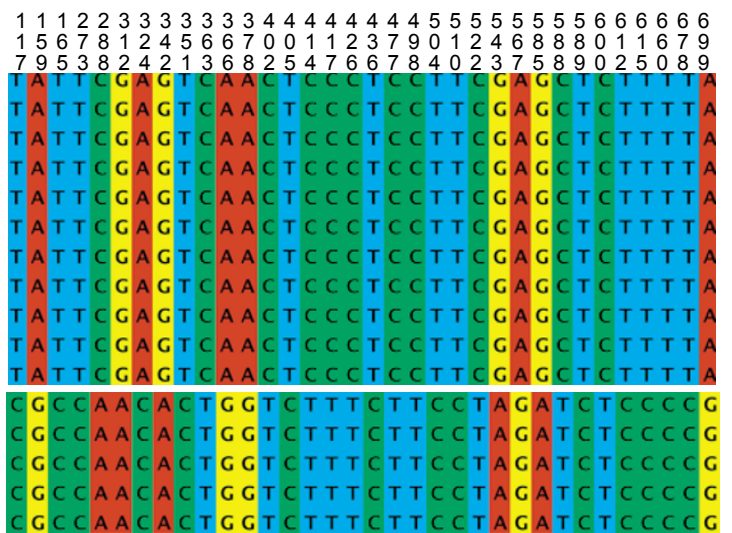

Penguins (Aptenodytes)

B

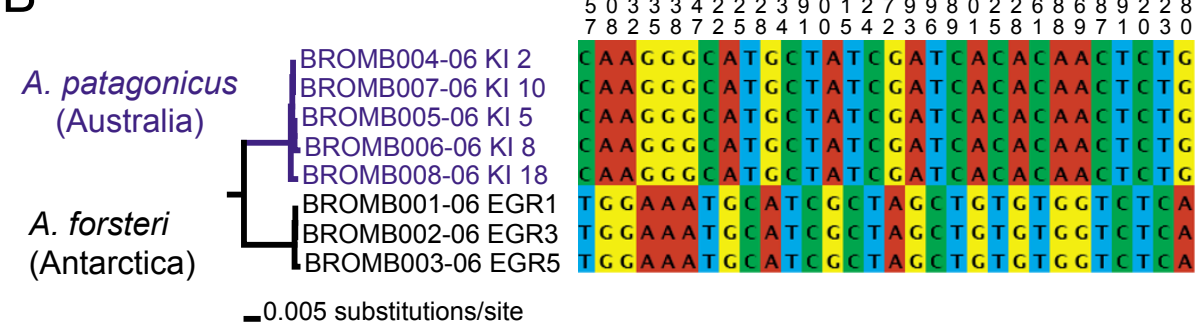

Goldeneyes (Bucephala)

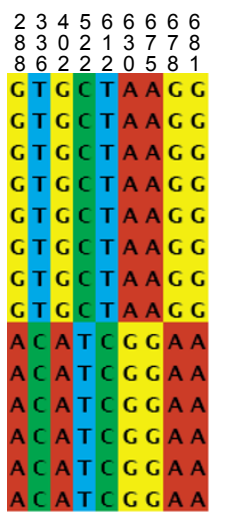

.0 .001 substitutions/site

\section{Figure I}

Examples of DNA barcodes distinguishing sister species. Neighbor-joining tree constructed with K2P genetic distances. Fixed substitutions are represented by coloured boxes, with corresponding character positions relative to the beginning of COI. a) Phalaropes (Phalaropus); b) Penguins (Aptenodytes); c) Goldeneyes (Bucephala). 
Table I: Comparisons of sister-species pairs from some major clades of birds. Sister-species pairs, probability of chance reciprocal phylogeny ( $p)$, and reference for phylogenetic relationship ( $r$ ).

\begin{tabular}{|c|c|c|c|c|c|c|c|}
\hline \multicolumn{2}{|c|}{ Sister-species pairs } & \multirow{2}{*}{$\frac{P}{4.7 \times 10^{-6}}$} & \multirow{2}{*}{$\begin{array}{l}r \\
{[52]}\end{array}$} & \multicolumn{2}{|c|}{ Sister-species pairs } & \multirow{2}{*}{$\begin{array}{l}P \\
9.7 \times 10^{-5}\end{array}$} & \multirow{2}{*}{$\begin{array}{l}r \\
{[53]}\end{array}$} \\
\hline Acridotheres tristis & A. ginginianus & & & Melospiza lincolnii & M. georgiana & & \\
\hline Actitis hypoleucos & A. macularius & $2.3 \times 10^{-4}$ & {$[47]$} & Mitu tuberosum & M. salvini & $5.0 \times 10^{-2}$ & {$[54]$} \\
\hline Aethia cristatella & A. psittacula & $4.1 \times 10^{-3}$ & {$[48]$} & Molothrus bonariensis & M. aeneus & $6.1 \times 10^{-4}$ & {$[55]$} \\
\hline Aethia pygmaea & A. cristatella & $4.1 \times 10^{-3}$ & {$[48]$} & Morus capensis & M. serrator & $5.1 \times 10^{-3}$ & {$[56]$} \\
\hline Aethia pygmaea & A. psittacula & $4.1 \times 10^{-3}$ & {$[48]$} & Numenius phaeopus & N. tahitiensis & $8.8 \times 10^{-4}$ & $\mathrm{a}$ \\
\hline Aptenodytes forsteri & A. patagonicus & $5.1 \times 10^{-3}$ & [49] & Passerina ciris & P. versicolor & $5.0 \times 10^{-2}$ & {$[57]$} \\
\hline Apteryx haastii & A. owenii & $2.0 \times 10^{-2}$ & {$[50]$} & Phalaropus fulicarius & P. lobatus & $3.1 \times 10^{-5}$ & $\mathrm{a}$ \\
\hline Apteryx mantelli & A. rowi & $4.2 \times 10^{-4}$ & {$[50]$} & Pheucticus melanocephalus & P. ludovicianus & $1.9 \times 10^{-3}$ & {$[58]$} \\
\hline Archilochus colubris & A. alexandri & $5.1 \times 10^{-3}$ & {$[59,60]$} & Picoides nuttallii & P. scalaris & $2.7 \times 10^{-2}$ & {$[61]$} \\
\hline Brachyramphus brevirostris & B. marmoratus & $7.6 \times 10^{-5}$ & [48] & Puffinus bulleri & P. pacificus & $2.0 \times 10^{-4}$ & {$[62]$} \\
\hline Bubo virginianus & B. scandiacus & $1.0 \times 10^{-5}$ & [63] & Pygoscelis antarcticus & P. papua & $1.4 \times 10^{-5}$ & {$[49]$} \\
\hline Bucephala clangula & B. islandica & $5.1 \times 10^{-5}$ & [64] & Recurvirostra americana & R. andina & $6.9 \times 10^{-3}$ & {$[65]$} \\
\hline Calamospiza melanocorys & Chondestes grammacus & $1.6 \times 10^{-2}$ & [53] & Rhea pennata & R. americana & $9.5 \times 10^{-3}$ & {$[66]$} \\
\hline Calcarius pictus & C. ornatus & $6.9 \times 10^{-3}$ & {$[67]$} & Rissa brevirostris & R. tridactyla & $2.8 \times 20^{-3}$ & {$[48]$} \\
\hline Tringa semipalmata & T. flavipes & $2.2 \times 10^{-5}$ & [47] & Spheniscus demersus & S. magellanicus & $9.5 \times 10^{-3}$ & {$[49]$} \\
\hline Centrocercus minimus & C. urophasianus & $1.6 \times 10^{-2}$ & [68] & Sialia currucoides & S. mexicana & $2.3 \times 10^{-4}$ & [69] \\
\hline Chlidonias leucopterus & C. niger & $1.6 \times 10^{-2}$ & [46] & Sialia sialis & S. mexicana & $4.5 \times 10^{-5}$ & [69] \\
\hline Cyanocitta cristata & C. stelleri & $5.1 \times 10^{-5}$ & [70] & Spizella breweri & S. passerina & $1.2 \times 10^{-6}$ & {$[53]$} \\
\hline Dendragapus fuliginosus & D. obscurus & $5.0 \times 10^{-2}$ & [7I] & Spizella pallida & S. breweri & $7.7 \times 10^{-5}$ & {$[53]$} \\
\hline Eudyptes pachyrhynchus & E. robustus & $2.7 \times 10^{-2}$ & [49] & Stercorarius parasiticus & S. longicaudus & $6.4 \times 10^{-6}$ & {$[72]$} \\
\hline Euphagus carolinus & E. cyanocephalus & $1.9 \times 10^{-3}$ & [73] & Hydroprogne caspia & Gelochelidonnilotica & $6.4 \times 10^{-6}$ & {$[46]$} \\
\hline Fratercula arctica & F. corniculata & $6.1 \times 10^{-4}$ & [48] & Thalasseus sandvicensis & T. elegans & $5.1 \times 10^{-5}$ & {$[46]$} \\
\hline Cerorhinca monocerata & Fratercula cirrhata & $3.0 \times 10^{-3}$ & [48] & Sternula antillarum & S. superciliaris & $9.5 \times 10^{-3}$ & {$[46]$} \\
\hline Tringa brevipes & T. incana & $2.0 \times 10^{-2}$ & [47] & Sturnella neglecta & S. magna & $2.3 \times 10^{-4}$ & {$[55]$} \\
\hline Himantopus himantopus & Hi. leucocephalus & $3.0 \times 10^{-3}$ & {$[65]$} & Sturnia malabarica & Temenuchus pagodarum & $1.0 \times 10^{-2}$ & {$[52]$} \\
\hline Himantopus melanurus & Hi. mexicanus & $9.5 \times 10^{-3}$ & {$[65]$} & Synthliboramphus antiquus & S. wumizusume & $2.7 \times 10^{-2}$ & {$[48]$} \\
\hline Icterus galbula & I. bullockii & $4.3 \times 10^{-4}$ & [74] & Toxostoma rufum & T. curvirostre & $1.0 \times 10^{-2}$ & {$[52]$} \\
\hline Jacana spinosa & J. jacana & $5.0 \times 10^{-2}$ & {$[75]$} & Tringa glareola & T. totanus & $2.2 \times 10^{-5}$ & {$[47]$} \\
\hline Lagopus muta & L. lagopus & $1.2 \times 10^{-6}$ & [76] & Tringa melanoleuca & T. nebularia & $2.3 \times 10^{-4}$ & {$[47]$} \\
\hline Limnodromus griseus & L. scolopaceus & $1.9 \times 10^{-3}$ & [77] & Uria aalge & U. lomvia & $2.3 \times 10^{-4}$ & {$[48]$} \\
\hline
\end{tabular}

a- genus comprising few species.

species were distinguished by $<10$ fixed nucleotide substitutional differences or had multiple intraspecific clusters. Probabilities of chance occurrence of reciprocal monophyly arising from random-branching within a single taxon were smaller than the level of significance $(\alpha)$ of $5 \%$ (Table 1). Ideally, larger sample sizes are required to increase the power of the test and to confirm reciprocal monophyly over a broad geographic range.

\section{Individuals were correctly assigned to their corresponding species}

Individuals from the six species-pairs with adequate samples sizes were picked randomly to query whether they could be assigned correctly to their species using clustering in a NJ tree, fixed mutations, and a statistical test of assignment based on coalescent theory [24] (Table 2, Figure 2). In all the cases the query individual was correctly assigned to species with posterior probability of 1.0 and correspondingly tiny risk of misassignment (Table 2, Figure 2). When species barcodes were comprised of more than one intraspecific cluster, as in Southern Brown Kiwi
(Apteryx australis, Figure 2A), Gull-billed Tern (Gelochelidon nilotica) and Gentoo Penguin (Pygoscelis papua), the query individual was assigned correctly to the each intraspecific cluster (Table 2).

\section{Species level delimitation with the "I0 $\times$ rule"}

Mean among sister-species distances of mtDNA barcodes varied from $0.78 \%$ to $11.77 \%$, with 20 out of 60 (28.6\%) distances smaller than the $2.7 \%$ threshold used to flag potential new species of birds. Among-species distances overlapped maximum within-species distances in 39 of 60 (65\%) sister-species pairs. Excluding cases that are likely to represent overlooked species based on other attributes, the overlap was observed in 21 of 60 sister-species pairs (35\%, Figure 3A). However, COI sequences in several species were structured in $\mathrm{NJ}$ trees into clades that represent geographically structured populations, recognized subspecies or possibly cryptic species (Table 3 ). The ratios of among-species to within-species distances were above 1 except for western and eastern populations of Eastern 

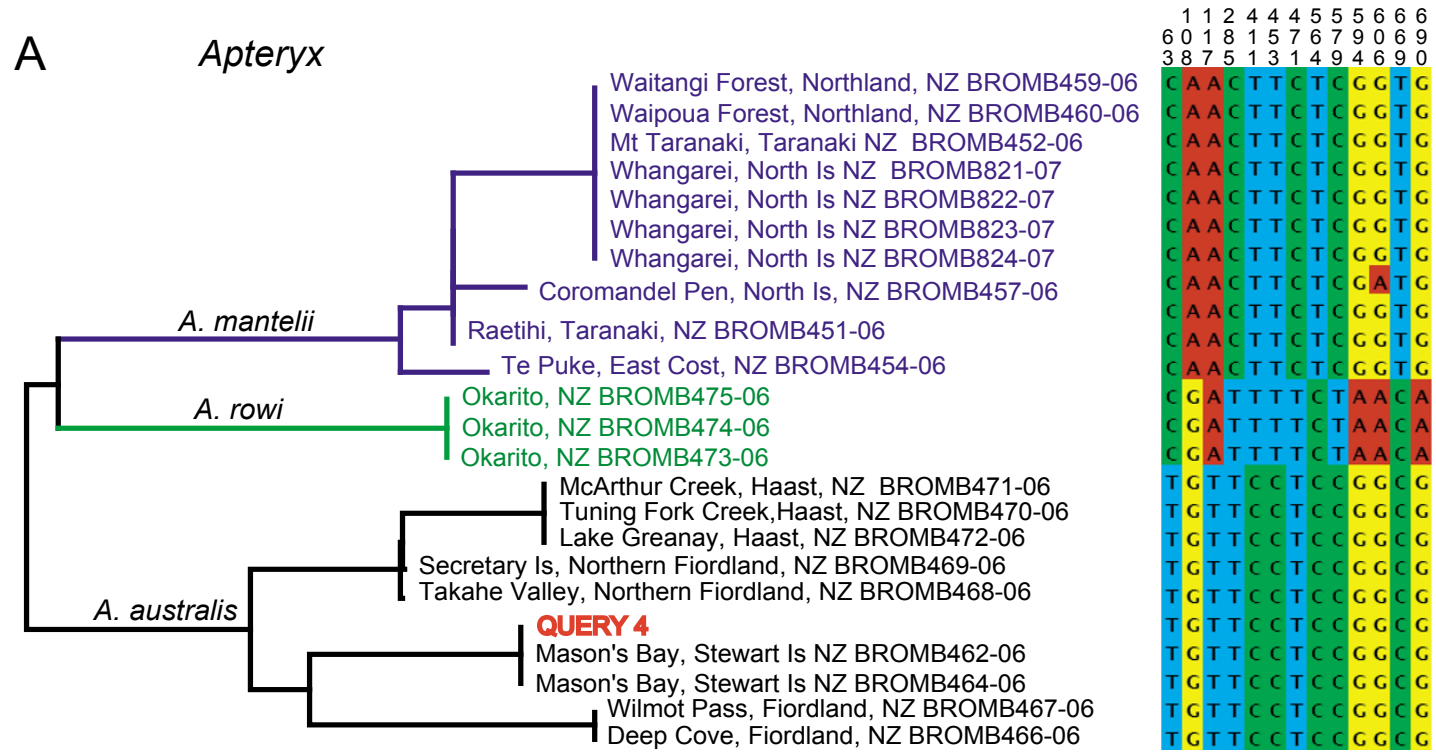

0.001 substitutions/site

B

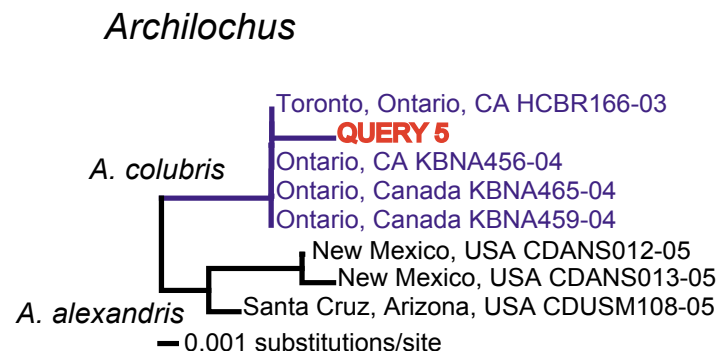

C

-0.001 substitutions/site

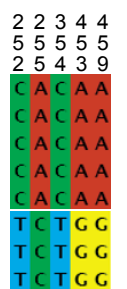

$$
\begin{aligned}
& \text { Thalasseus } \\
& \text { QUERY } 3 \\
& \text { T.s.acuflavida Louisiana, USA KKBNA768-05 } \\
& \text { T.s. acuflavida Florida, USA CDUSM032-05 } \\
& \text { T.s.eurygnatha Rio Grande do Sul, BR BROM043-06 } \\
& \text { T.s. acuflavida Florida, USA CDUSM031-05 } \\
& \text { T.s.eurygnatha Salinas, Para, BR BROM009-06 } \\
& \text { T.s.acuflavida Florida, USA KKBNA229-05 }
\end{aligned}
$$

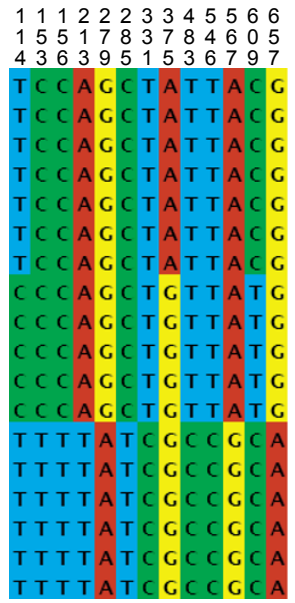

\section{Figure 2}

Assignment of unknowns. Neighbor-joining tree constructed with K2P genetic distances. Fixed substitutions are represented by coloured boxes, with corresponding character positions relative to the beginning of COI. Query specimens used in the test of assignment are indicated in red, with additional information in Table 2. a) Okarito Brown Kiwi (Apteryx rowi); b) Ruby-throated Hummingbird (Archilochus colubris); c) Sandwich Tern (Thalasseus sandvicensis). 
Table 2: Assignment of individuals to species. Query individual to be assigned, specimen details, diagnostic sites, posterior probability of assignment (Post. prob.), and risk of mis-assignment.

\begin{tabular}{|c|c|c|c|c|c|}
\hline Query Species & Specimen ID. & Collecting locale & $\begin{array}{l}\text { Diagnostic } \\
\text { sites (\#) }\end{array}$ & Post. prob. & Risk \\
\hline $\begin{array}{l}\text { I. Common Goldeneye Bucephala } \\
\text { clangula }\end{array}$ & $1510-10045$ & Labrador, Canada & 9 & 1 & $1.815 \times 10^{-46}$ \\
\hline 2. Lincoln's Sparrow Melospiza lincolnii & KKBNAIII-4 CWSL94-6576I-04 & Saskatchewan, Canada & 9 & 1 & $6.661 \times 10^{-34}$ \\
\hline 3. Sandwich Tern Thalasseus sandvicensis & KKBNA472-05 UWBM 73832 & Louisiana, USA & 11 & 1 & $4.315 \times 10^{-31}$ \\
\hline 4. Okarito Brown Kiwi Apteryx rowi & BROMB463-06 RA 0886 & Stewart Is., New Zealand & 13 & 1 & $1.568 \times 10^{-37}$ \\
\hline $\begin{array}{l}\text { 5. Ruby-throated Hummingbird } \\
\text { Archilochus colubris }\end{array}$ & TZBNA028-03 IB-269 & Ontario, Canada & 7 & 1 & $1.946 \times 10^{-16}$ \\
\hline 6. Gentoo Penguin Pygoscelis papua & GPBI & Falkland Islands & 35 & 1 & $2.831 \times 10^{-99}$ \\
\hline
\end{tabular}

Meadowlark (Sturnella magna) which are thought to be two species $[11,25]$ (Figure 3B).

Plots of corrected COI distances against divergence times revealed that mutations are accumulating roughly linearly in all the groups we evaluated (Figure 4). However, the rates of evolution are variable. For example, shanks accumulate more mutations in COI than do terns and penguins per unit time (Figures 4, and 5A-C). Variation in rates of evolution of $\mathrm{COI}$ in different clades of birds mitigates against a universal distance criterion for species recognition, in accordance with previous evidence from a mitogenomic timescale for birds [26].

\section{Intraspecific variation suggesting potential distinctive taxonomical entities}

Six species had distinctive intraspecific clusters with probabilities of chance reciprocal monophyly below a conservative level of $\alpha=1 \%$ : Kittlitz's Murrelet (Brachyramphus brevirostris), Gentoo Penguin (Pygoscelis papua), Gullbilled Tern (Gelochelidon nilotica), Eastern Meadowlark (Sturnella magna), Common Redshank (Tringa totanus), and Little Penguin (Eudyptula minor, Table 3, Figure 6). These groups represent recognized subspecies, populations occupying different geographical areas or distinct morphotypes. DNA barcode sequences of Gelochelidon nilotica comprised three intraspecific clusters in NJ trees (Figure 6C, Table 3). Two of the groups had discontinuous beak size distributions (pers. obs.) that were thought to represent Australian and Asian subspecies S. n. macrotarsa and S. n. affinis, respectively [27]. The other group comprised reciprocally monophyletic lineages representing the subspecies $S$. $n$. groenvoldi (South America) and $S$. n. vanrossemini (Russia), but they were poorly sampled ( 2 samples each) [28].

Using the test for chance reciprocal monophyly, the Little Penguins of Australia and New Zealand, respectively, currently lumped into Eudyptula minor, are probably two species (Table 3 ). This conclusion is supported by a high number of fixed differences in the DNA barcodes and in multigene phylogenies [29] (Table 3, Figure 6A). Other species are comprised of monophyletic groups that could be taxonomically distinctive, although the probabilities of chance reciprocal monophyly are between 1-5\%. For example, specimens of Australasian Pipit (Anthus novaeseelandiae) from New Zealand and Australia differ by $4.1 \%$ in their barcodes, and Little Terns (Sterna albifrons) from England and Australia differ by about 1\%. However, increased sampling of these species is required to properly test whether they represent separate taxonomic entities.

\section{Discussion \\ Effectiveness of single gene $\mathrm{COI}$ barcodes}

Our study of 60 pairs of sister species from a broad range of bird clades showed that closely related pairs could not be distinguished using the $10 \times$ rule of among to within species divergence, as predicted by critics of this criterion $[12,15]$. Similarly, the suggested threshold genetic distance of $2.7 \%$ to flag potential species failed to detect recently evolved sister species, and was further compromised by substantial variation in the rate of COI evolution in different clades and short species divergence times. However, all sister-species pairs were shown to possess unique DNA barcodes by which they could be identified. In particular, the COI sequences of even very closely related sister species were found to have diagnostic combinations of 5-64 fixed substitutional differences that better fit the analogy of a short DNA barcode. Individuals were correctly assigned to each sister species for which we had moderate sample sizes $(\mathrm{N} \geq 4)$ using different lines of evidence: NJ clustering, diagnostic fixed substitutions, and a decision-theoretic framework based on coalescent theory implemented in Assigner [24]. The concern about assigning taxonomically unknown specimens to an existing or new taxon is unlikely to be a serious problem in birds, given the uniqueness of species barcodes and the mature taxonomy of the clade.

Phylogroups of COI sequences representing within-species variation can potentially be confounded with recently diverged sister species, so to objectively discriminate 
A

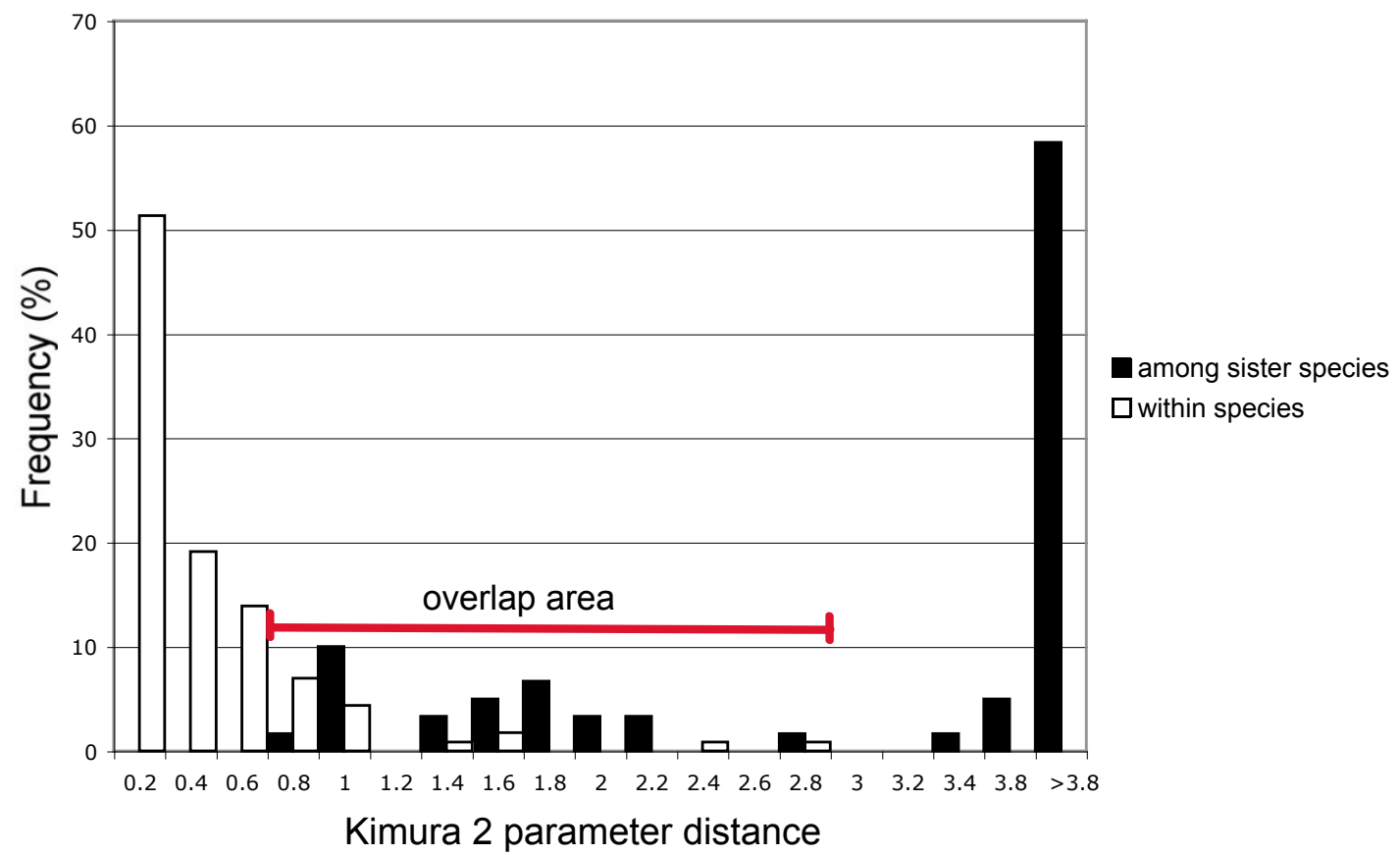

B

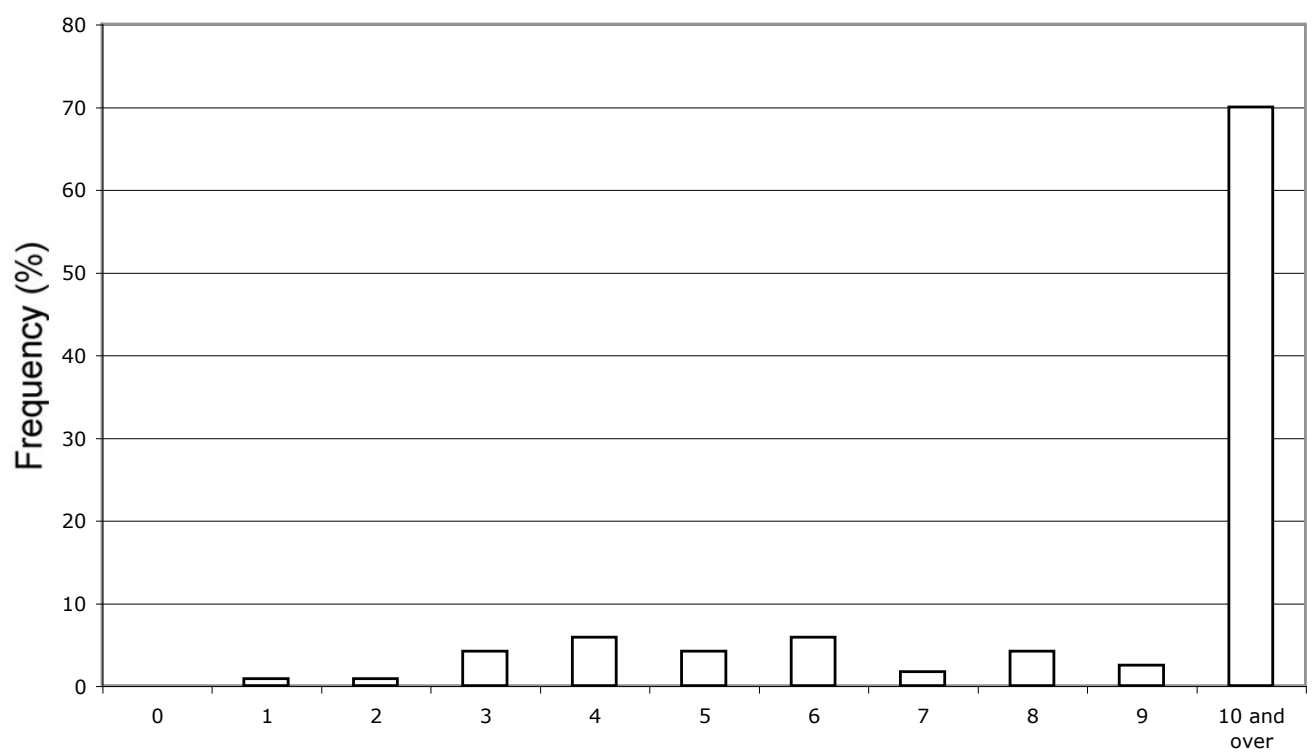

Interspecific: intraspecific distance ratio

Figure 3

Levels of intraspecific and interspecific distances of sister-species of birds. a) Frequency distribution of K2P intraspecific and interspecific genetic distances between sister-species. b) Frequency distribution of the ratios of K2P interspecific: intraspecific distances in sister species of birds. 
between these two possibilities we applied a statistical test of the null hypothesis that reciprocal monophyly has arisen by random branching of lineages within a single species. The null hypothesis could be rejected in all closely related sister species $(P<0.05)$, verifying the power of the test. In addition, putative new species were strongly supported by the distinctive signatures of $>12$ fixed substitutional differences and low probabilities of chance reciprocal monophyly within a single species. For example, the barcodes of Little Penguins from Australia and New Zealand, and of Gentoo Penguins from Macquarie Island and the Falklands, provide strong inferences of separate lineages that may warrant species status for these groups. The existence of separately evolving metapopulation lineages is the species delimitation criterion for a recently proposed unified species concept [30], though contingent properties such as phenetic, behavioural and reproductive differences need to be assessed in future to provide additional lines of evidence for or against species status. This is not a weakness of a single mtDNA gene barcoding system as has been claimed [21], but rather is a rapid way to discover monophyletic lineages within a metapopulation that might represent undiscovered cryptic species. The barcoding approach used here can be applied to other organismal groups where individuals of the same species cluster in monophyletic clades despite overlaps in within- and among-species variation [14]. However, will not be applicable in groups with no mitochondrial divergence observed between species pairs (ex. [31]).

\section{Single gene versus multilocus approaches for species delimitation}

One of the most cogent criticisms of single locus mtDNA barcodes is that a pattern of reciprocal monophyly in maternally inherited genes can also arise when female dispersal is very restricted, often contrasting with widespread apparent panmixia of autosomal and paternally inherited genes [32]. However, if sister species have diverged very recently then sufficient time may not have passed for enough mutations in a nuclear gene to have accumulated to reliably track lineage splitting and resolve problems with incomplete sorting of ancestral polymorphism. This in turn can lead to erroneous inference of extensive gene flow in autosomal genes if it is based on single gene trees. In such situations use of multiple nuclear genes is increasingly being touted to help delimit species boundaries [2123]. Recent simulations in a coalescent-based approach showed that species limits were delimited with high probability depending on the number of loci examined and the timing of species divergence [21]. Ten loci were able to reliably detect species with effective population sizes of 100,000 that diverged in a timeframe $(31,000$ generations ago) when incomplete lineage sorting would be expected to occur. Obviously, this multilocus approach is currently infeasible for the purpose of barcoding life on the planet, but it will be invaluable for inferring species limits in very recently separated species pairs where mtDNA barcodes alone might not be definitive. The 60 previously identified sister-species pairs of birds we studied had unique mtDNA barcodes that identified them, and each species was characterized by fixed mutational differences that are unlikely to be reduced substantially in number by increased sampling of polymorphic sites. However, species in which well differentiated reciprocally monophyletic clades of COI haplotypes were detected would seem to be fertile ground for further investigation with independent multiple nuclear gene trees in a coalescent framework. For example, the split between Australian and New Zealand populations of Little Penguins was dated at approximately 1.3 Mya using the neutral coalescent method in IM [33], and a phylogenetic rate of COI evolution of 0.01354 substitutions/site/Myr [26]. Given a generation time of 6.5 years (based age of first breeding of 2.5 years and annual survival of breeding adults $80 \%$ [34] this equates roughly to 200,000 generations, where incomplete lineage sorting of autosomal genes should be reduced unless effective population size is very large [35]. The faster sorting of COI sequences might be an advantage in identifying possible recent speciation events, and they can be combined with nuclear gene sequences in IM to estimate whether the divergence is due to isolation or if gene flow has been ongoing. Thus we view DNA barcodes as useful complements in multigene data sets that might include more than one mtDNA gene [36], contrary to recent criticisms of maternally inherited genes in species delimitation.

\section{Conclusion}

We show that in a broad range of birds even closely related sister species delimited with independent evidence could be identified with mtDNA barcodes and diagnostic substitutions using standard COI sequences. All pairs were characterized by reciprocally monophyletic lineages, and tests of the null hypothesis of random branching within a single species were rejected. Thus in well studied groups like birds, mtDNA barcodes are extremely effective in identifying sister species. In species that are shown by COI barcodes to be comprised of several divergent monophyletic lineages that might flag unrecognized species, it is important to test these splits with multiple independent gene trees in a coalescent framework to guard against the alternative inference of population subdivision via restricted female dispersal. Combination of multiple genes including mtDNA barcodes should counter any biases in species detection and the high variance in associated genetic processes [21]. 
Table 3: Possible taxonomically distinctive entities. Intraspecific clusters of individuals that might be unrecognized species, probability of chance reciprocal monophyly ( $p, \alpha \leq 0.01)$, specimen details, fixed diagnostic mutations, and mean distances between the clusters of the same species.

\begin{tabular}{|c|c|c|c|c|}
\hline Species & $\mathrm{P}$ & Collecting locale or subspecies (sampling) & Fixed mutations & Mean D (\%) among clusters \\
\hline \multirow[t]{2}{*}{ Brachyramphus brevirostris } & $3.0 \times 10^{-3}$ & a. Aleutians, Russia (3) & $a$ vs $b=7$ & $a$ vs $b=1.23$ \\
\hline & & b. East Alaska (6) & & \\
\hline \multirow[t]{2}{*}{ Pygoscelis papua } & $9.7 \times 10^{-5}$ & a. Macquarie Island (6) & $a$ vs $b=15$ & $a$ vs $b=2.43$ \\
\hline & & b. Falkland Island (7) & & \\
\hline \multirow[t]{3}{*}{ Gelochelidon nilotica } & $1.8 \times 10^{-3}$ & a. Small form of the beak (3) & $a$ vs $b=11$ & $a$ vs $b=1.74$ \\
\hline & $9.5 \times 10^{-3}$ & b. Large form of the beak ( 3 ) & a vs $c=10$ & a vs $c=1.84$ \\
\hline & & c. South America, Russia (4) & b vs $c=5$ & $\mathrm{~b}$ vs $\mathrm{c}=1.74$ \\
\hline \multirow{2}{*}{ Sturnella magna } & $9.5 \times 10^{-3}$ & a. Texas (4) & $a$ vs $b=22$ & $a$ vs $b=4.03$ \\
\hline & & b. Texas, Ontario, Miami (3) & & \\
\hline \multirow[t]{2}{*}{ Tringa totanus } & $9.5 \times 10^{-3}$ & a. Iceland (4) & $a$ vs $b=6$ & $a$ vs $b=0.95$ \\
\hline & & b. Vietnam, Australia (3) & & \\
\hline \multirow[t]{2}{*}{ Eudyptula minor } & $8.3 \times 10^{-17}$ & a. New Zealand (NZ)(2I) & $a$ vs $b=28$ & $a$ vs $b=3.82$ \\
\hline & & b. Australia (2I) & & \\
\hline
\end{tabular}

COI evolution: sister-species level

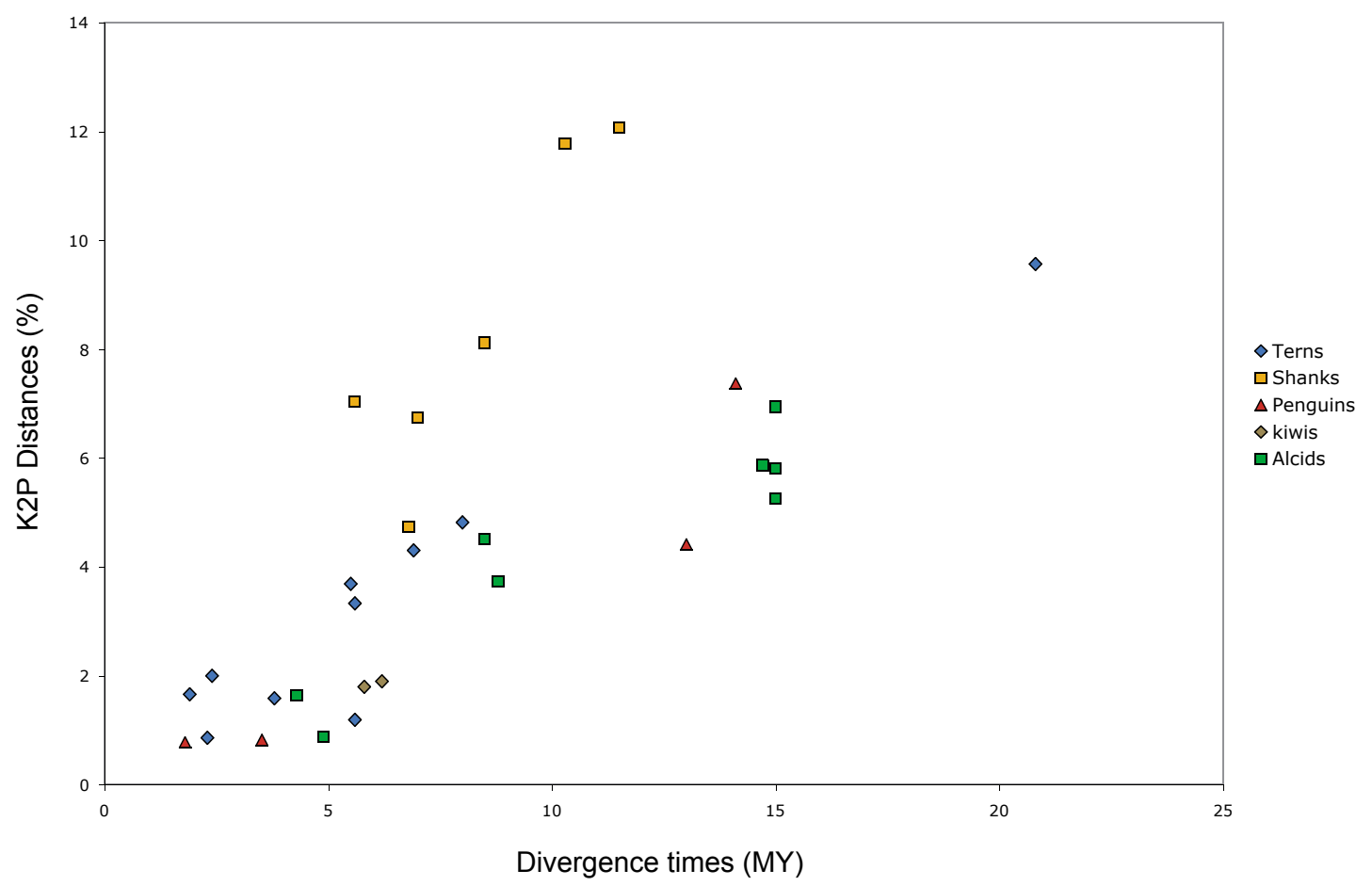

\section{Figure 4}

Variable rates of $\mathrm{COI}$ evolution in different lineages of birds. lot of the $\mathrm{K} 2 \mathrm{P}$ genetic distances among sister-species versus divergence times obtained from chronograms of different clades of birds. 
A
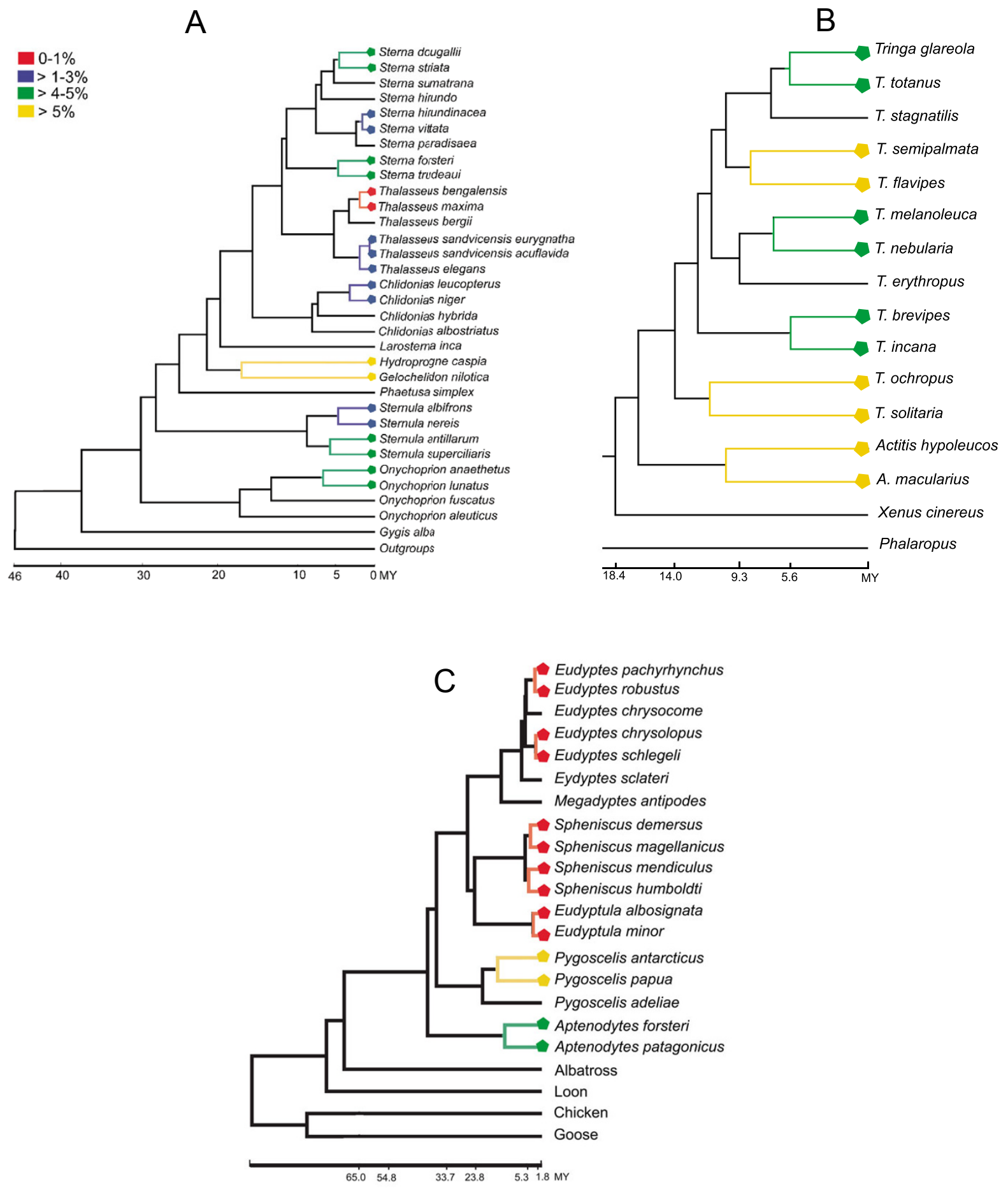

Figure 5

K2P distances of DNA barcodes mapped on chronograms of different lineages of birds. hronograms of diverse clades of birds. Legend correspond to K2P divergence levels in DNA barcodes : a) terns; b) shanks, and c) penguins. 
Little Blue Penguin (Eudyptula minor)

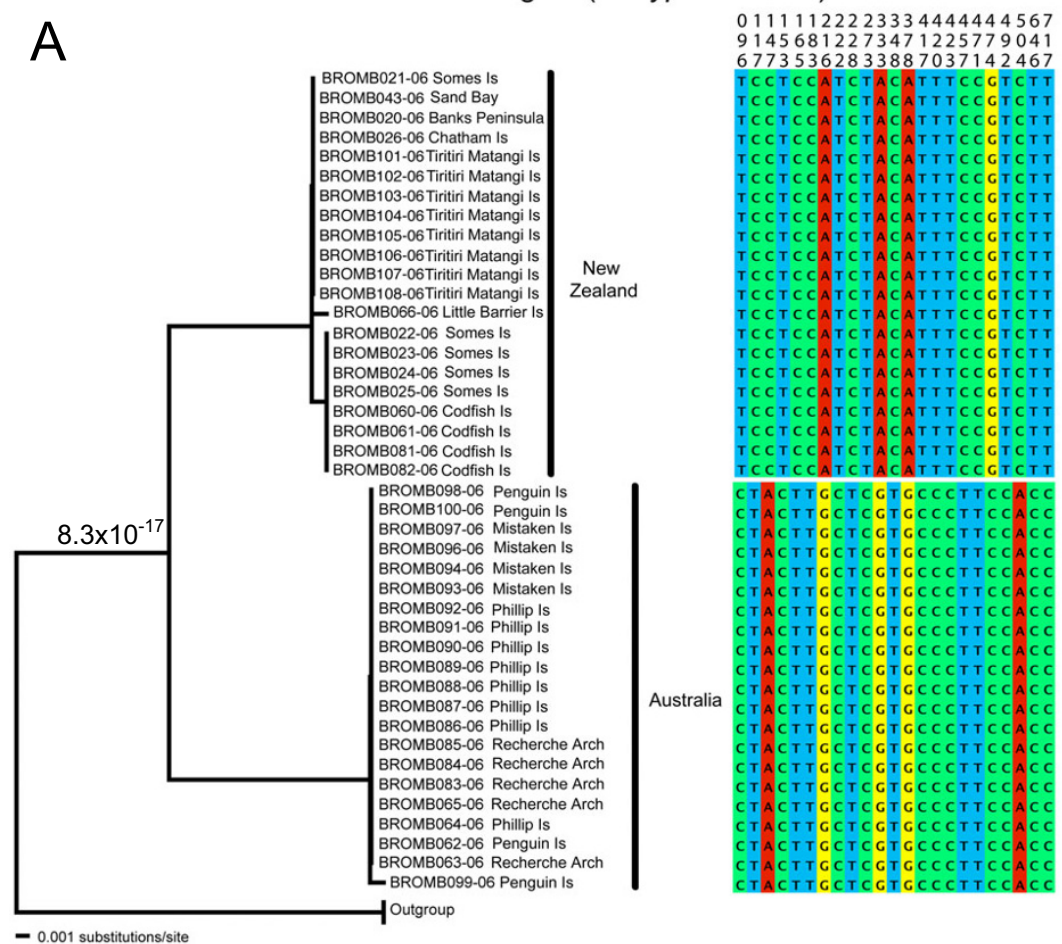

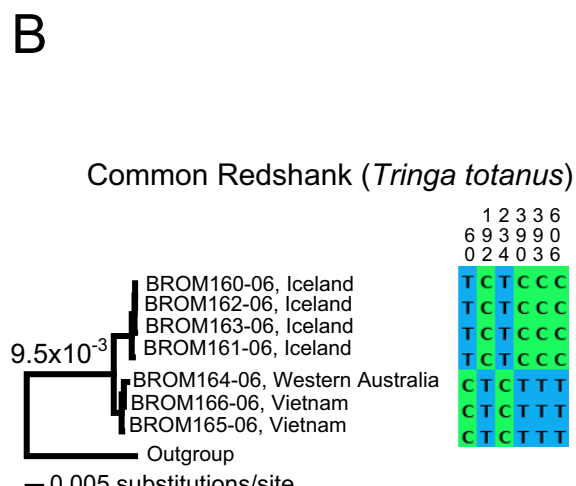

- 0.005 substitutions/site

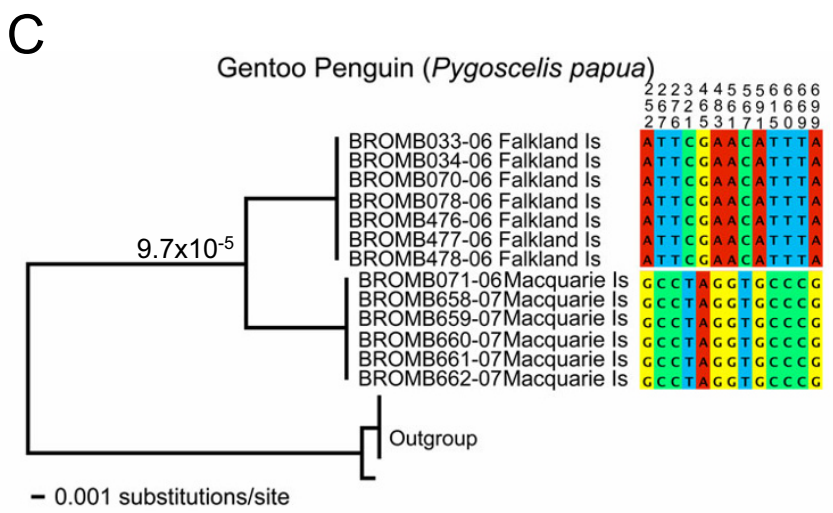

-0.001 substitutions/site

\section{Figure 6}

Reciprocally monophyletic groups possibly indicating unrecognized species. eighbor-joining tree constructed with $\mathrm{K} 2 \mathrm{P}$ genetic distances. Fixed substitutions are represented by coloured boxes, with corresponding character positions relative to the beginning of COI. a) Little Penguin (Eudyptula minor); b) Common Redshank (Tringa totanus) and, c) Gentoo Penguin (Pygoscelis papua).

\section{Methods}

\section{Taxon sampling}

To evaluate the performance of COI barcoding in detecting species boundaries of birds we analyzed sister-species pairs defined rigorously by previous phylogenetic studies (Table 1). We excluded species that were known to hybridize to prevent confusion due to introgression, a problem that plagues all methods of species delimitation. In addition, we included species of birds with multiple clusters that might represent unrecognized species. The COI sequences generated and used in this work are deposited in the project "Royal Ontario Museum- Birds 1 " in the 
Completed Projects selection of the Barcode of Life Data System (BOLD [37], Genbank Accession numbers EU525241-EU525592). COI sequences obtained from previous work are available in the Completed Projects selection of the BOLD, in the "Birds of North America" project [10,11] (Genbank Accession numbers DQ432694-DQ433261， DQ433274-DQ433846, DQ434243-DQ434805).

\section{DNA extraction and sequencing}

DNA was extracted from blood, muscle or liver by phenol, chelex or a membrane purification procedure with glass fiber filtration plates (Acroprep 96 Filter Plate- $1.0 \mu \mathrm{m}$ Glass, PALL Corporation [38]). PCR amplification of the $5^{\prime}$ end of the COI gene were performed in a $12.5 \mu \mathrm{L}$ reaction, with a buffer solution containing $10 \mathrm{mM}$ Tris- $\mathrm{HCl}$, $\mathrm{pH} 8.3,50 \mathrm{mM} \mathrm{KCl}, 2.5 \mathrm{mM} \mathrm{MgCl}_{2}, 0.01 \%$ gelatin, and $160 \mu \mathrm{g} / \mathrm{ml}$ bovine serum albumin (BSA) [39], $0.4 \mathrm{mM}$ dNTPs, $0.2 \mu \mathrm{M}$ of each primer, $1 \mathrm{U}$ Taq polymerase (Invitrogen), and 20-25 ng of DNA. Cycle conditions were 36 cycles of $94^{\circ} \mathrm{C}$ for $40 \mathrm{~s}, 50^{\circ} \mathrm{C}$ for $40 \mathrm{~s}$, and $72^{\circ} \mathrm{C}$ for $1 \mathrm{~m}$, with an initial denaturation of $94^{\circ} \mathrm{C}$ for $5 \mathrm{~m}$ and a final extension at $72^{\circ} \mathrm{C}$ for $7 \mathrm{~m}$. Bird universal primers used were as follows: LTyr - TGTAAAAAGGWCTACAGCCTAACGC, (Oliver Haddrath, pers. comm.) and COI907aH2 - GTRGCNGAYGTRAARTATGCTCG, (Rebecca Elbourne, pers. comm.) Amplified segments were purified by excising bands from agarose gels and centrifuging each through a filter tip. Sequences were obtained on an ABI3100 (Applied Biosystems) according to the manufacturers' suggested protocols using the internal primers COIaRt (forward-AACAAACCACAAAGATATCGG, Oliver Haddrath, pers comm.) and COI748Ht (reverse-TGGGARATAATTCCRAAGCCTGG), or alternatively LTyr (primer used in amplification) and COI745h 2 (reverse-ACRTGNGAGATRATTCCRAANCCNG, Rebecca Elbourne, pers. comm.). Sequences were checked for ambiguities in Sequencher 4.1.2 (GeneCodes Corp., Ann Arbor, Michigan) and the multiple alignments was performed in MacClade 4 [40].

\section{Species delimitation with DNA barcodes}

To check for reciprocal monophyly in sister-species with DNA barcodes, a Neighbor-Joining (NJ) tree was constructed in PAUP 4.10b [41] with the Kimura 2 parameter model (K2P). Statistical support was estimated with 1,000 bootstrap replicates in a heuristic search using stepwise addition with 10 random additions of sequences.

Because compound diagnostic characters are a valuable source of information to diagnose species [18] we filtered variable characters for each sister-species pairs in PAUP $4.10 \mathrm{~b}$ [41], and fixed substitutions were selected in MacClade 4 [40].
The test for chance occurrence of reciprocal monophyly [19] was applied to the sister-species pairs with $\alpha=5 \%$. We also performed this test on 'intraspecific' clusters of individuals that might represent distinct taxonomical unities, and additional species from which the barcodes were available in our database, or in public databases (Genbank, BOLD, see Table 3[42]). Additionally, as an example on Little Penguins, we used the non-equilibrium coalescent approach implemented in the program IM, where an ancestral population splits into two constantsized populations in the past and potentially exchange migrants [43]. Modal values of the population mutation parameter $(\theta)$, time of population divergence (tpop), time to the most recent common ancestor (TMRCA) and scaled migration rate $(\mathrm{M})$ were obtained from the posterior distributions of these parameters using a Monte Carlo Markov Chain run for 12.26 million generations after a burnin of 100,000 generations.

\section{Assignment test}

The correct assignment of individuals to species was performed in a decision-theoretic framework based on coalescent theory in Assigner [24]. The species selected had a ratio of among-species:maximum within-species genetic distances $<10$, and with $\mathrm{N} \leq$ four individuals (Common Goldeneye, Lincoln's Sparrow, Sandwich Tern, and Gentoo Penguin). The COI sequence of one randomly selected individual was excluded from the matrix and used as the query sequence. For each of the sister species of the pair (target groups), the evolutionary parameter $\theta$ (twice the product of the female effective population size and neutral mutation rate) with corresponding maximum likelihood was estimated from the data in FLUCTUATE [44]. These values were used to calculate the likelihood of each of the target groups after re-including the query sequence to be assigned in Assigner [24].

\section{Distance and threshold estimation}

Distances under the K2P model were calculated among sister-species and within-species in MEGA 3.1 [45]. Complete deletion was used in each comparison, to keep the number of base pairs equal in intra- and interspecific comparisons. Because the precision of the mtDNA barcode relies on the expectation that within-species variation is lower than among-species variation [1], the mean estimate of among species distances and the maximum value of pairwise intraspecific distances were used in the comparisons. The average level of intraspecific variation estimated across 260 species of birds of North America ( $0.27 \%$ of sequence divergence, yielding a threshold of $2.7 \%$ sequence divergence) [11] was used to test the efficacy of the $10 \times$ rule in the sister-species pairs. To evaluate how variation in rates of evolution of COI in different lineages of birds [26] affect distance comparisons at sisterspecies levels, we selected six clades of birds for which 
divergence times have been estimated previously with relaxed clock methods (terns [46], shanks [47], alcids [48], penguins [49], and kiwis [50]). K2P distances of species pairs were plotted against divergence times, and COI distances between sister species of Terns, Shanks and Penguins were mapped on the corresponding chronograms.

\section{Authors' contributions}

AJB and EST designed the scope of the research. EST carried out the lab work, data assembly, and analysis except for coalescent simulations in IM which were done by AJB. Both authors wrote and approved the final manuscript.

\section{Additional material}

\section{Additional file 1}

Sister-species differences in COI barcode sequences. Sister-species pairs and sampling, fixed substitutions (fixed subst.), bootstrap support, mean interspecific K2P distances $\left(D_{\text {inter }}\right)$, and maximum intraspecific K2P distance within each species $\left(D_{\text {intra }}\right)$.

Click here for file

[http://www.biomedcentral.com/content/supplementary/14712148-8-81-S1.xls]

\section{Additional file 2}

Neighbor-joining tree topology constructed from DNA barcodes of sister species of birds. Neighbor-joining tree topology of 650 bp of mitochondrial gene COI, under the K2P model and pairwise deletion. File in nexus format, opens in TreeView.

Click here for file

[http://www.biomedcentral.com/content/supplementary/1471-

2148-8-81-S2.tre]

\section{Acknowledgements}

We thank Rebecca Elbourne for providing some of the sequences, and the Zoological Museum University of Copenhagen, South Australian Museum, Louisiana State University Museum of Natural Science, Field Museum of Natural History, University of Michigan Museum of Zoology, American Museum of Natural History, Burke Museum of Natural History and Culture, and Bell Museum of Natural History for kindly permitting us to barcode loaned samples. We thank two anonymous referees for useful comments on the manuscript. This work was supported by funding through the Canadian Barcode of Life Network from Genome Canada through the Ontario Genomics Institute, NSERC, and other sponsors [5I], and the ROM Governors' Fund.

\section{References}

I. Hebert PD, Cywinska A, Ball SL, deWaard JR: Biological identifications through DNA barcodes. Proc Biol Sci 2003, 270(15 I 2):3|3-32I.

2. Stoeckle MY: Taxonomy, DNA and the bar code of life. BioScience 2003, 53:2-3.

3. Hebert PD, Gregory TR: The promise of DNA barcoding for taxonomy. Syst Biol 2005, 54(5):852-859.

4. Ward RD, Zemlak TS, Innes BH, Last PR, Hebert PD: DNA barcoding Australia's fish species. Philos Trans R Soc Lond B Biol Sci 2005, 360( (1462): | $847-1857$.

5. Hebert PD, Penton EH, Burns JM, Janzen DH, Hallwachs W: Ten species in one: DNA barcoding reveals cryptic species in the neotropical Skipper Butterfly Astraptes fulgerator. Proc Natl Acad Sci USA 2004, I 0 I(4I): I48I 2-I48I7.

6. Janzen DH, Hajibabaei M, Burns JM, Hallwachs W, Remigio E, Hebert PD: Wedding biodiversity inventory of a large and complex Lepidoptera fauna with DNA barcoding. Philos Trans $R$ Soc Lond B Biol Sci 2005, 360(| 462): | 835-| 845 .

7. Lambert DM, Baker A, Huynen L, Haddrath O, Hebert PD, Millar CD: Is a large-scale DNA-based inventory of ancient life possible? $J$ Hered 2005, 96(3):279-284.

8. Smith MA, Fisher BL, Hebert PD: DNA barcoding for effective biodiversity assessment of a hyperdiverse arthropod group: the ants of Madagascar. Philos Trans R Soc Lond B Biol Sci 2005, 360(1462): 1825-1834.

9. Pook CE, McEwing R: Mitochondrial DNA sequences from dried snake venom: a DNA barcoding approach to the identification of venom samples. Toxicon 2005, 46(7):7II-7I 5 .

10. Kerr KCR, Stoeckle MY, Dove CJ, Weigt LA, Francis CM, Hebert PDN: Comprehensive DNA barcode coverage of North American birds. Mol Ecol Notes 2007, 7(4):535-543.

II. Hebert PD, Stoeckle MY, Zemlak TS, Francis CM: Identification of Birds through DNA Barcodes. PLoS Biol 2004, 2(10):e3I2.

12. Moritz C, Cicero C: DNA barcoding: promise and pitfalls. PLoS Biol 2004, 2( I 0):e354.

13. Meyer CP, Paulay G: DNA barcoding: error rates based on comprehensive sampling. PLoS Biol 2005, 3(I 2):e422.

14. Meier R, Shiyang K, Vaidya G, Ng PK: DNA barcoding and taxonomy in Diptera: a tale of high intraspecific variability and low identification success. Syst Biol 2006, 55(5):715-728.

15. Hickerson MJ, Meyer CP, Moritz C: DNA barcoding will often fail to discover new animal species over broad parameter space. Syst Biol 2006, 55(5):729-739.

16. Rubinoff $D$ : Utility of mitochondrial DNA barcodes in species conservation. Conserv Biol 2006, 20(4):1026-1033.

17. Will KW, Mishler BD, Wheeler QD: The perils of DNA barcoding and the need for integrative taxonomy. Syst Biol 2005, 54(5):844-85I.

18. DeSalle R, Egan MG, Siddall M: The unholy trinity: taxonomy, species delimitation and DNA barcoding. Philos Trans $R$ Soc Lond B Biol Sci 2005, 360( | 462): 1905-1916.

19. Rosenberg NA: Statistical tests for taxonomic distinctiveness from observations of monophyly. Evolution 2007, 6 I (2):3 17-323.

20. Avise JC: Phylogeography: The History and Formation of Species. Cambridge, Massachusetts , Harvard University Press; 2000:447.

21. Knowles LL, Carstens BB: Delimiting species without monophyletic gene trees. Syst Biol 2007, 56(6):887-895.

22. Maddison WP, Knowles LL: Inferring phylogeny despite incomplete lineage sorting. Syst Biol 2006, 55:2I-30.

23. Edwards SV, Liu L, Pearl DK: High-resolution species trees without concatenation. Proc Natl Acad Sci USA 2007, 104:5936-594I.

24. Abdo Z, Golding GB: A step toward barcoding life: a modelbased, decision-theoretic method to assign genes to preexisting species groups. Syst Biol 2007, 56(I):44-56.

25. Wells MG: World bird species checklist: With alternative English and scientific names. Bushey, Worldlist; 1998:67I.

26. Pereira SL, Baker AJ: A mitogenomic timescale for birds detects variable phylogenetic rates of molecular evolution and refutes the standard molecular clock. Mol Biol Evol 2006, 23(9): $173 \mid-1740$.

27. Rogers DI, Collins P, Jessop RE, Minton CDT, Hassell CJ: Gull-billed Terns in north-western Australia: subspecies identification, moults and behavioural notes. Emu 2005, I05(2): 145-I58.

28. Molina KC, Erwin RM: The distribution and conservation status of the Gull-billed Tern (Gelochelidon nilotica) in North America. Waterbirds 2006, 29(3):27I-295.

29. Banks JC, Mitchell AD, Paterson AM: An unexpected pattern of molecular divergence within the Blue Penguin (Eudyptula minor) complex. Notornis 2002, 49:29-38.

30. De Queiroz K: Species concepts and species delimitation. Syst Biol 2007, 56(6):879-886.

31. Neigel J, Domingo A, Stake J: DNA barcoding as a tool for coral reef conservation. Coral Reefs 2007, 26(3):487-499.

32. Irwin DE: Phylogeographic breaks without geographical barriers to gene flow. Evolution 2002, 56( I 2):2383-2394.

33. Hey J, Nielsen R: Multilocus methods for estimating population sizes, migration rates and divergence time, with applications 
to the divergence of Drosophila pseudoobscura and D. persimilis. Genetics 2004, 167(2):747-760.

34. Saether BE, Lande R, Engen S, Weimerskirch H, Lillegard M, Altwegg $\mathrm{R}$, Becker PH, Bregnballe T, Brommer JE, McCleery RH, Merila J, Nyholm E, Rendell W, Robertson RR, Tryjanowski P, Visser ME Generation time and temporal scaling of bird population dynamics. Nature 2005, 436(7047):99-102.

35. Hudson RR, Coyne JA: Mathematical consequences of the genealogical species concept. Evolution 2002, 56(8): I557-I565.

36. Pons J, Barraclough TG, Gomez-Zurita J, Cardoso A, Duran DP Hazell S, Kamoun S, Sumlin WD, Vogler AP: Sequence-based species delimitation for the DNA taxonomy of undescribed insects. Syst Biol 2006, 55(4):595-609.

37. Barcode of Life Data System [http://www.barcodinglife.org]

38. Ivanova NV, DeWaard JR, Hebert PDN: An inexpensive, automation-friendly protocol for recovering high-quality DNA. Mol Ecol Notes 2006, 6:998-1002.

39. Hagelberg E: Mitochondrial DNA from ancient bones. In Ancient DNA Edited by: Herrmann B, Hummel S. New York, Springer; 1994:195-204

40. Maddison WP, Maddison DR: MacClade 4: Analysis of Phylogeny and Character Evolution. Version 4.08 edition. 2005 [http://mac clade.org]. Sunderland, Sinauer Associates, Inc

41. Swofford DL: PAUP*: Phylogenetic Analysis Using Parsimony (*and related methods) . 4th edition. 2002 [http:// paup.csit.fsu.edu/]. Sunderland, Sinauer Associates

42. Ratnasingham S, Hebert PDN: BOLD: The Barcode of Life Data System. Mol Ecol Notes 2007, 7(3):355-364

43. Nielsen R, Wakeley JW: Distinguishing migration from isolation: an MCMC approach. Genetics 200I, 158:885-896.

44. Kuhner MK, Yamato J, Felsenstein J: Maximum likelihood estimation of population growth rates based on the coalescent Genetics 1998, 149(1):429-434.

45. Kumar S, Tamura K, Nei M: MEGA3: Integrated software for Molecular Evolutionary Genetics Analysis and sequence alignment. Brief Bioinform 2004, 5(2): 150-163.

46. Bridge ES, Jones AW, Baker AJ: A phylogenetic framework for the terns (Sternini) inferred from mtDNA sequences: implications for taxonomy and plumage evolution. Mol Phylogenet Evol 2005, 35(2):459-469.

47. Pereira SL, Baker AJ: Multiple gene evidence for parallel evolution and retention of ancestral morphological states in the shanks (Charadriiformes: Scolopacidae). Condor 2005, 107:514-526.

48. Pereira SL, Baker AJ: DNA evidence for a Paleocene origin of the Alcidae (Aves: Charadriiformes) in the Pacific and multiple dispersals across northern oceans. Mol Phylogenet and Evol 2008, 46(2):430-445.

49. Baker AJ, Pereira SL, Haddrath OP, Edge KA: Multiple gene evidence for expansion of extant penguins out of Antarctica due to global cooling. Proc Biol Sci 2006, 273( I 582): I - I7.

50. Burbidge ML, Colbourne RM, Robertson HA, Baker AJ: Molecular and other biological evidence supports the recognition of at least three species of brown kiwi. Conserv Genet 2003, 4:167-177.

5I. The Canadian Barcode of Life Network [http://www.BOL NET.ca]

52. Lovette IJ, Rubenstein DR: A comprehensive molecular phylogeny of the starlings (Aves: Sturnidae) and mockingbirds (Aves: Mimidae): congruent mtDNA and nuclear trees for a cosmopolitan avian radiation. Mol Phyl Evol 2007 44(3): $1031-1056$

53. Carson RJ, Spicer GS: A phylogenetic analysis of the emberizid sparrows based on three mitochondrial genes. Mol Phylogenet Evol 2003, 29(I):43-57.

54. Pereira SL, Baker AJ, Wajntal A: Combined nuclear and mitochondrial DNA sequences resolve generic relationships within the Cracidae (Galliformes, Aves). Syst Biol 2002, 5 I (6): $946-958$.

55. Freeman S, Zink RM: A phylogenetic study of the blackbirds based on variation in mitochondrial DNA restriction sites. Syst Biol I 995, 44(3):409-420.

56. Friesen VL, Anderson D): Phylogeny and evolution of the Sulidae (Aves:Pelecaniformes): a test of alternative modes of speciation. Mol Phylogenet Evol 1997, 7(2):252-260.
57. Klicka J, Fry AJ, Zink RM, Thompson CW: A cytochrome-b perspective on Passerina bunting relationships. Auk 200I, II 8(3):610-623.

58. Klicka J, Zink RM: The importance of recent ice ages in speciation: a failed paradigm. Science 1997, 277:1666-1669.

59. Rusch KM, Thusius K, Ficken MS: The organization of agonistic vocalizations in Ruby-throated Hummingbirds with a comparison to Blackchinned Hummingbirds. Wilson Bulletin 200I, I I 3(4):425-430.

60. Baltosser $\mathrm{WH}$ : Annual molt in Ruby-throated and Blackchinned Hummingbirds. Condor 1995, 97(2):484-491.

61. Moore SM, Weibel AC, Agius A: Mitochondrial DNA phylogeny of the woodpecker genus Veniliornis (Picidae, Picinae) and related genera implies convergent evolution of plumage patterns. Biol J Linnean Soc 2006, 87:6 | I-624.

62. Austin J], Bretagnolle $\mathrm{V}$, Pasquet E: A global molecular phylogeny of the small Puffinus shearwaters and implications for systematics of the Little-audubon's shearwater complex. Auk 2004, I 2 I (3):847-864

63. Wink M, Sauer-Gürth H, Fuchs M: Phylogenetic relationships in owls based on nucleotide sequences of mitochondrial and nuclear marker genes.: 2004; Budapest, Hungary. Edited by: Chancellor RD, Meyburg BU. World Working Group on Birds of Prey and Owls and Birdlife Hungary; 2003:890.

64. Livezey BC: Phylogeny and evolutionary ecology of modern seaducks (Anatidae: Mergini). Condor 1995, 97:233-255.

65. Pierce RJ: Family Recurvirostridae. In Handbook of the Birds of the World Volume 3. Edited by: del Hoyo J, Elliott A, Sargatal J. Barcelona , Lynx Edicions; 1996:821.

66. Yamada K, Nishida-Umehara C, Matsuda Y: Characterization and chromosomal distribution of novel satellite DNA sequences of the Lesser Rhea (Pterocnemia pennata) and the Greater Rhea (Rhea americana). Chromosome Res 2002, I0(6):5। 3-523.

67. Klicka J, Zink RM, Winker K: Longspurs and snow buntings: phylogeny and biogeography of a high-latitude clade (Calcarius). Mol Phylogenet Evol 2003, 26(2): $165-175$.

68. Oyler-McCance SJ, Kahn NW, Burnham KP, Braun CE, Quinn TW: A population genetic comparison of large- and small-bodied sage grouse in colorado using microsatellite and mitochondrial DNA markers. Mol Ecol 1999, 8(9): | 457-| 465.

69. Shawkey MD, Balenger SL, Hill GE, Johnson LS, Keyser AJ, Siefferman $\mathrm{L}$ : Mechanisms of evolutionary change in structural plumage coloration among bluebirds (Sialia spp.). J R Soc Interface 2006 , 3(9):527-532.

70. Bonaccorso E, Peterson AT: A multilocus phylogeny of New World jay genera. Mol Phylogenet Evol 2007, 42(2):467-476.

7I. Drovetski SV: Molecular phylogeny of grouse: individual and combined performance of $\mathrm{W}$-linked, autosomal, and mitochondrial loci. Syst Biol 2002, 5 I (6):930-945.

72. Cohen BL, Baker AJ, Blechschmidt K, Dittmann DL, Furness RW Gerwin JA, Helbig AJ, de Korte J, Marshall HD, Palma RL, Peter HU, Ramli R, Siebold I, Willcox MS, Wilson RH, Zink RM: Enigmatic phylogeny of skuas (Aves:Stercorariidae). Proc Biol Sci 1997, 264(I379): $|8|-190$

73. Lanyon SM, Omland KE: A molecular phylogeny of the blackbirds (Icteridae): Five lineages revealed by cytochrome-b sequence data. Auk 1999, I I6(3):629-639.

74. Omland KE, Lanyon SM, Fritz SJ: A molecular phylogeny of the New World orioles (Icterus): the importance of dense taxon sampling. Mol Phylogenet Evol 1999, I 2(2):224-239.

75. Whittingham LA, Sheldon FH, Emlen ST: Molecular phylogeny of jacanas and its implications for morphologic and biogeographic evolution. Auk 2000, II 7(I):22-32

76. Lucchini V, Hoglund J, Klaus S, Swenson J, Randi E: Historical biogeography and a mitochondrial DNA phylogeny of grouse and ptarmigan. Mol Phylogenet Evol 200I, 20(I): 149-162.

77. Thomas GH, Wills MA, Szekely T: A supertree approach to shorebird phylogeny. BMC Evol Biol 2004, 4:28. 